Павленко В. В., кандидат юридичних наук

\title{
ВИБОРИ ТА ВИБОРЧА СИСТЕМА В УКРАЇНІ: ІСТОРИКО-ПРАВОВИЙ АНАЛІЗ
}

\begin{abstract}
Анотація. Актуальність статті полягає в тому, що за час незалежності Україна скористалася усіма існуючими виборчими моделями: мажоритарною, пропорційною та змішаною. Але, на жаль, слід визнати, що вибори в Україні у посткомуністичний період проходили і проходять зазвичай із використанням методів адміністративного тиску, широко застосовується підкуп населення, залякування кандидатів та виборців. У статті аналізується становлення виборчої системи в Україні. Розкривається суть понять «вибори» та «виборча система», показано вітчизняний та зарубіжний досвід їх розвитку. Визначається роль виборів для будь-якої демократичної держави. Розглядаються шляхи подальшого розвитку виборчої системи в Україні. Наголошується на необхідності вивчення історії виборчої системи нашої держави. Окреслено концептуальні підходи удосконалення виборчого законодавства України. Наголошено, що політико-правовий вимір виборчої системи інтегрує правовий і політичний аспекти виборчого процесу і означає порядок організації i проведення виборів до представницьких органів влади і здійснення громадянами своїх виборчих прав. У цьому разі виборча система розглядається як елемент політичної системи, яка організовує та обслуговує інститут виборів встановленим законом або іншим нормативним актом способом визначення результатів голосування і порядком розподілу мандатів між партіями і кандидатами. 3'ясовано, що суб'єктивне виборче право, зокрема в Україні, традиційно закріплюється Конституцією і розглядається як гарантоване державою право громадянина України вільно обирати та бути обраним до виборних органів публічної влади (державної влади і місцевого самоврядування). При цьому виокремлюються активне (право обирати) та пасивне (право бути обраним) виборче право. Зроблено висновок, що виборча система - це врегульована конституційно-правовими нормами (в сукупності утворюють конституційно-правовий інститут виборчого права) система суспільних відносин, які складаються в рамках врегульованого законом порядку організації та проведення вільних виборів, як форми прямої демократії та безпосереднього народовладдя, завдяки якій отримують можливість на законних підставах (легально) та на основі загальносуспільного визнання (легітимно) функціонувати представницькі органи публічної влади на окремому історичному етапі розвитку суспільства.
\end{abstract}

Ключові слова: вибори, виборча система, виборче законодавство, історико-правовий аналіз, народовладдя.

Актуальність теми. Сьогодні, коли Україна проходить складний шлях розбудови незалежної держави важливо забезпечити стабільне $\mathrm{i}$ продуктивне функціонування базових інститутів демократії. Тому вибори і виборче право безумовно стають фундаментом демократії і належать до основних засад конституційного ладу нашої держави.
Якщо говорити про народовладдя, яке означає належність усієї повноти влади народу, то воно напряму залежить від типу виборчої системи, яку застосовують у тій чи іншій країні світу. Треба сказати, що за час незалежності Україна скористалася усіма існуючими виборчими моделями: мажоритарною, пропорційною та змішаною. Але, на жаль, слід визнати, що вибори в Україні у посткомуністичний період проходили і проходять, як правило, із використанням методів адміністративного тиску, широко застосовується підкуп населення, залякування кандидатів та виборців. Попри те, що у 2014 році було проголошено курс на європейську інтеграцію, вибори в нашій державі досі не набули демократичного наповнення. Саме ця обставина змушує в черговий раз говорити про актуальність дослідження виборчої системи в Україні задля удосконалення вітчизняного законодавства та політичної системи загалом.

Виправити ситуацію, на наш погляд, може врахування міжнародних стандартів щодо організації та проведення виборів, розроблення доктринальної концепції сучасної національної виборчої системи, яка має грунтуватися не лише на чіткому розумінні основ виборчого права, а й на створенні оптимальної моделі виборів, яка б звела до мінімуму вплив суб'єктивного фактора на здійснення народного волевиявлення. Крім того, як ніколи треба приділити увагу ретельному вивченню вітчизняного досвіду, особливо проблемам, пов'язаним зі становленням виборчої системи у період Української революції 1917-1921 pp., в радянську добу та в період перебування українських етнічних територій у першій пол. XX ст. у складі таких європейських країн як Чехословаччина, Румунія, Польща.

В історично-правовій науці ще й досі вітчизняні дослідники розглядають трансформацію виборчої системи $\mathrm{i}$ всього, що 3 нею пов' язано, здебільше фрагментарно, у контексті вивчення окремих інститутів виборчого права, безпосередньої демократії, місцевого самоврядування тощо. Тому, актуальним, на нашу думку, залишається цілісний аналіз природи й еволюції виборчої системи в умовах становлення, розвитку та занепаду окремих форм української державності у першій половині XX ст.

В основі статті лежить провідна ідея інтеграції досвіду, що вивчений через концепт історично-правової науки, з сучасними інноваційними підходами до удосконалення виборчої системи України, як однієї з необхідних умов забезпечення справжнього волевиявлення громадян.

Стан дослідження. Із початком процесу демократизації суспільного життя та становленням багатопартійності у 80-90-х рр. минулого століття утворилися сприятливі умови для об'єктивного наукового аналізу політико-правових систем розвинутих країн світу та вивчення можливості застосування ïх досвіду. У цей час, за досить короткий період, на пострадянському просторі, в тому числі й в Україні, з'явилося достатньо широке коло досліджень, присвячених проблемам теорії 
та історії розвитку демократії, формуванню і функціонуванню інститутів виборчої системи у демократичному суспільстві. Йдеться про праці В. Бабкіна, Г. Каменської, А. Ковлера, М. Марченка, О. Підгорної, С. Рябова, В. Селіванова, А. Требкова, Б. Страшуна та інших $[3 ; 2 ; 17 ; 29 ; 33 ; 40 ; 37 ; 23 ; 39 ; 38]$. У цих роботах висвітлено основні етапи розвитку демократії, оскільки цей процес безпосередньо впливає на систематизацію правових норм, у тому числі й на виборчі права громадян.

Варто наголосити, що 3 часів отримання незалежності стають доступними як для наукової громадськості, так і для широкого загалу, роботи західних дослідників, зокрема Р. Даля [11], Р. Дарендорфа [12], Ж. Зіллера [16], Д. Каррі [18], А. Лейпхарта [28], К. Поппера [34], Дж. Сарторі [36], А. Токвіля [38]. Автори цих праць розкривають міжнародні стандарти виборчого права, висвітлюють сучасні форми та методи забезпечення демократичного народного волевиявлення, акцентують увагу на тому, що демократичність держави визначається не проголошеною формою державного устрою, а саме рівнем реальної участі громадян в управлінні державними справами. Необхідно наголосити, що саме ці вчені у своїх роботах звертають увагу на міжнародні стандарти прав людини, а це на думку автора, $€$ дуже важливим.

Йдеться про реалізацію права особи брати участь у виборах, референдумах і плебісцитах. Автори вказаних праць наголошують, що вибори та інші електоральні процеси розглядаються світовим співтовариством як один із ключових факторів внутрішньодержавних владних відносин,що мають системоутворюючий характер і визначають увесь «вигляд» національної і політичної системи. 3 таким ствердженням не можна не погодитися.

Виклад основного матеріалу. Говорячи про сучасні міжнародні стандарти проведення виборів, референдумів, плебісцитів, також варто звернути увагу на те, що цей процес фактично розпочався у першій половині XX ст., а точніше після завершення Першої світової війни. Необхідно зазначити, що «на той час норма про вільне волевиявлення була, по суті, тестом на розуміння демократії взагалі» [33, с. 278].

У 20-х рр. XX ст. вибори, виборче право, виборчий процес займають дедалі вагоміше місце і набувають усе більшого значення в міжнародному праві. I хоча утвердження універсальних правил організації волевиявлення громадян у повоєнний період проходило складно, але цей процес відбувався «в результаті природних зовнішньополітичних акцій, які за своєю суттю $€$ відбитком умонастроїв, рівня розвитку політичної і правової культури, рівня правової свідомості держав, які іх робили та які не мислили ці акції іншими, але ще не надавали їм характеру загальних, $з$ погляду усвідомлення важливості процесів демократизації суспільства для всієї людської цивілізації [7, с. 137].

Сьогодні у сучасному міжнародному праві сформувався нормативний масив міжнародних стандартів виборчого законодавства, розроблений країнами, де демократія не є порожнім звуком. Зрозуміло, що фундаментом тут є міжнародні стандарти у сфері прав людини, а точніше - міжнародні стандарти у міжнародному праві прав людини [6]. Крім того, зазначені стандарти - це ще й міжнародно-правові зобов'язання держави, які розвивають та конкретизують принцип поваги прав людини.

Треба сказати, що міжнародні стандарти поширюються і на місцеве самоврядування, у сфері якого виникають та здійснюються практично всі життеві прагнення конкретної людини, таким чином реалізуючи всі її права та свободи.
Тому можна зробити висновок, що міжнародні стандарти прав людини, в тому числі й міжнародні виборчі стандарти, це принципи, які регулюють коло досить складних суспільних відносин і $€$ важливими для демократичної держави, яка керується нормами міжнародного права та міжнародних угод. Держави, які підписали відповідні документи і визнають зазначені норми, беруть на себе зобов'язання щодо їх закріплення у своєму законодавстві та наступної реалізації у практичній діяльності суб' єктів права, які перебувають на їх юрисдикційній території.

Аналізуючи нормативні підходи до визначення i закріплення міжнародних виборчих стандартів, необхідно з'ясувати структуру таких стандартів. На нашу думку, тут можна погодитися із Б. Кофманом, який до елементів структури таких стандартів відносить: а) міжнародні стандарти виборчого права; б) міжнародні стандарти виборчого законодавства; в) міжнародні стандарти виборчого процесу; г) міжнародні стандарти участі громадськості в електоральній демократії [26, с. 79].

Досліджуючи історію становлення виборчої системи в Україні, безумовно, не можна оминути і таке поняття, як принципи виборчого права. Йдеться про основні, найзагальніші вихідні положення, засоби, правила, які визначають природу і соціальну сутність цього поняття. Крім того, принципи виборчого права встановлюють рамки, в яких існує і діє механізм правового регулювання виборчих взаємовідносин, та є основою, на якій формується правова регламентація цих відносин.

Не підлягає сумніву, на думку автора, і те, що принципи виборчого права становлять фундамент регулювання виборчих правовідносин. Вони також відображають сутність організації та підготовки виборів, реалізацію конституційних прав громадян брати участь в управлінні державою, вільно обирати та бути обраними до органів публічної влади.

На наш погляд, наведені принципи $є$ обов'язковими вимогами та умовами, які дають підстави визнавати вибори легітимними. Тут слід звернути увагу на наявність в українській історіографії думки про те, що вітчизняному виборчому законодавству «варто уникати вживання окремо терміна «принципи» без терміна «засади», об'єднавши їх в одному понятті «засади виборчого процесу» та «засади виборчого права» [21, с. 4].

Наступним, на чому хотілося 6 наголосити, $€$ те, що особливе значення має конституційне закріплення принципів виборчого права, оскільки саме Конституція є базою національного законодавства. Принципи, які встановлює Конституція, визначають у подальшому параметри всього законодавчого регулювання i $€$ критерієм оцінки законодавства, яке приймається та діє. Тут якраз дуже важливо, коли Конституція закріплює основні принципи організації виборів і участі в них суб'єктів та учасників виборчого процесу, оскільки вибори і виборчі права становлять одну $з$ основ політичної системи. Варто також звернути увагу на те, що в нині діючій Конституції України відповідно до міжнародно-правових документів у ст. 71 прописано норму, яка рівною мірою впливає як на активне, так і на пасивне виборче право: «Вибори до органів державної влади та органів місцевого самоврядування $є$ вільними і відбуваються на основі загального, рівного і прямого виборчого права шляхом таємного голосування. Виборцям гарантується вільне волевиявлення» [25].

Сьогодні українськими науковцями ще не напрацьовано єдиної класифікації принципів виборчого права, отже $€$ декілька поглядів на це питання. Авторці статті найбільше 
імпонує точка зору Ю.Б. Ключковського, який систематизує принципи виборчого права таким чином: а) принципи, які стосуються виборів у цілому, вимагають, щоб вони були: загальними, прямими, рівними, вільними, чесними; б) принципи, що стосуються голосування і передбачають: таємне голосування, особисте голосування, однократне голосування, факультативне голосування» $[20$, с. 43$]$.

$€$ й інша класифікація принципів виборчого права, надана Л.М. Козодоєм, який обгрунтовує іiї призначенням механізму правового регулювання виборчих відносин [22, с. 109]. За цією ознакою принципи можна поділити на організацію та проведення виборів, а також на участь громадян у виборах. Крім того, В.В. Кравченко поміж принципів виборчого права виокремлює ті, які прямо стосуються забезпечення та реалізації виборчих прав громадян, і ті, що стосуються інших суб'єктів виборчого процесу 3 точки зору їх юридичної сили. Дослідник констатує, що «принципи виборчого права - це умови його визнання і здійснення, які разом забезпечують реальний характер волевиявлення народу, легітимність виборчих органів публічної влади. Ці принципи зафіксовані у відповідних міжнародно-правових документах» [27, с. 151].

Необхідно звернути увагу і на те, що проблематика формування інститутів представницької системи врядування не одразу зайняла чільне місце в українській правовій науці. Кількасотрічний колоніальний i напівколоніальний статус українських земель кликав вітчизняних дослідників на шлях наукового та соціального пошуку, насамперед в одному генеральному напрямі, який коротко можна визначити словами «боротьба за українську державність». Проте провідні учасники цього пошуку прагнули осягнути історичну перспективу боротьби і чимало зробили для розробки принципових засад політичного та державного устрою майбутньої української держави. Не залишилися поза їх увагою і світовий досвід формування та функціонування представницької системи i, певна річ, можливості його використання на українському грунті.

Варто згадати М. Драгоманова, який у своїх працях [14] активно і наполегливо обгрунтовував переваги представницького правління, як єдино прийнятного для майбутньої демократичної української держави. Він навіть розробив власний проєкт побудови їі владних інститутів. Чимало цікавих ідей щодо формування та функціонування представницьких органів влади висунув М. Грушевський $[9 ; 10$, с. 210].

У своїх працях ці вчені звертають увагу на тривалу історію становлення парламентаризму в Україні, яка почалася ще з часів існування віча за княжої доби. Існує думка, що саме віче надавало правлінню київських князів найбільш демократичного характеру [13].

Беззаперечним фактом $€$ те, що активний інтерес до питань виборів і виборчої системи зародився у вітчизняному правознавстві ще із середини XIX - початку XX ст. У цей час відбувається становлення парламентаризму. Праці цього періоду вирізняються наративно-публіцистичним стилем та ідейною заангажованістю, що відображало своєрідність політичної боротьби в українському суспільстві на початку XX ст.

Що стосується періоду становлення та розвитку виборчої системи після завершення Першої світової війни, то значним здобутком історіографії зазначеної теми $є$ монографічні та дисертаційні дослідження, в яких йдеться про вивчення провідного інституту представницької демократії в Україні - парламента- ризму. Тут передусім слід згадати працю «Український парламентаризм: минуле і сучасне», підготовлену вченими інституту держави і права ім. В.М. Корецького НАН України за участі науковців інших установ та практичних працівників [41]. У цій праці висвітлюється історія формування, утвердження та вдосконалення українського парламентаризму. Зрештою, це видання можна назвати першою працею такого роду в Україні, де, в загальних рисах, висвітлюється історія українського парламентаризму.

Крім того, можна ще згадати монографії О.М. Бандурки та Ю.Д. Древаля «Парламентаризм в Україні: становлення і розвиток», а також Ю.Д. Древаля «Парламентаризм у політичній системі України (політико-правовий аналіз)» [4; 15]. Автори вказаних праць пов'язують становлення парламентаризму в Україні з періодом діяльності австро-угорського та російського імперських парламентів.

Без сумніву, вибори $€$ одним із ключових моментів політичного самоутвердження громадян, а разом із тим - юридичного визнання за ними права брати участь в управлінні державою. Такий механізм може бути дієвим і справедливим за умови функціонування ефективної і демократичної виборчої системи, яка має забезпечити процедуру формування представницьких органів влади. Як зазначено у «Популярній юридичній енциклопедії), «порядок організації і проведення виборів до представницьких органів та формування виборчих органів держави» [35, с. 51] прийнято називати виборчою системою, яку ще визначають як систему суспільних відносин, що існуе у сфері формування складу представницьких органів шляхом виборів.

Отже, виборчу систему слід розглядати як політико-правовий інститут, що дає змогу поєднати нормативно-правовий підхід 3 описом виборчої системи як суспільно-політичного явища, яке знаходить свій вияв у відповідних правових відносинах $[19$, с. $5 ; 31]$.

Досліджуючи трансформацію виборчої системи України у будь-яких хронологічних рамках, потрібно визначитися з розумінням цього терміну у історико-правовому значенні.

Поняття «виборча система» поєднує в собі два терміни - «вибори» та «система», які у взаємозв'язку детермінують ії зміст. У науковій літературі поширені такі поняття, як «вузьке» та «широке» 24 , с. 200; 42, с. 362]. Зауважимо: вживання термінів «вузьке» та «широке» розуміння правових явищ демонструє відсутність чітко вираженої гносеологічної чи онтологічної ідентифікації виборчої системи як об'єкта наукового аналізу. Безумовно, це $\epsilon$ перешкодою щодо змістового визначення базового для дослідження історико-правового поняття «виборча система».

Узагальнений аналіз літератури дає підстави для висновку, що у «вузькому» розумінні виборча система розглядається як електоральна формула, спосіб визначення результатів виборів, нормативно регулятивним рівнем виборчої системи [32, с. 107; 8, с. 43]. У «широкому» ж розумінні, окрім зазначеного фактора, мова йде ще й про інституційний простір, у якому перебувають суб̆'єкти виборчого процесу (держава, політичні сили, електорат), а також те, що слугує своєрідним «вестибулярним» апаратом системи - її інформаційно-комунікативна структура $[1$, c. 56]. У дослідженнях на цю тему наголошується на цілісному процесі формування виборчих органів державної влади і органів місцевого самоврядування, включаючи організацію 
і проведення виборів, а також визначення їхніх результатів і відповідний розподіл депутатських мандатів [30, с. 268].

Таким чином, у вузькому розумінні, виборча система - це спосіб визначення результатів виборів, що зводиться до математичного алгоритму, певної сукупності дій, які необхідно виконати 3 числовими даними, отриманими внаслідок голосування, щоб визначити розподіл мандатів у виборчому органі. А у широкому (політико-правовому) розумінні, виборча система означає порядок організації і проведення виборів до представницьких органів влади, місцевого самоврядування та здійснення громадянами своїх прав. У доктринальному розумінніце вся сукупність врегульованих законом механізмів і процедур виборів - від призначення виборів до оголошення результатів та реєстрації обраних під час виборів.

Якщо поєднати «вузьке» $\mathrm{i}$ «широке» розуміння виборчої системи, можна дійти висновку, що в політологічному вимірі виборча система, як політичний інститут - це сукупність правил, прийомів і процедур, що забезпечують і регулюють легітимне формування державних представницьких органів політичної влади. У юридичному вимірі виборчу систему слід розуміти як правовий інститут, тобто як сукупність норм, що регулюють відповідні правовідносини.

Політико-правовий вимір виборчої системи інтегрує правовий і політичний аспекти виборчого процесу і означає порядок організації і проведення виборів до представницьких органів влади і здійснення громадянами своїх виборчих прав. У цьому разі, виборча система розглядається, як елемент політичної системи, яка організовує та обслуговує інститут виборів, встановленим законом, або іншим нормативним актом способом визначення результатів голосування і порядком розподілу мандатів між партіями і кандидатами. Правовий аспект цього процесу кореспондується 3 усією сукупністю встановлених законом правил організації і проведення виборів, критеріїв і способів визначення їхніх результатів. Мова йде, по-перше, про закріплення принципів, на основі яких відбуваються вибори, а також право громадян обирати та бути обраними. По-друге, йдеться про регулювання суспільних відносин, які виникають у процесі організації і проведення виборів в органи державної влади і місцевого самоврядування. По-третє, про встановлення гарантії виборчих прав громадян і відповідальність депутатів та інших обраних осіб перед виборцями [30, с. 268].

Розгляд виборчої системи як елементу правової системи, передбачає аналіз взаємозалежності предмету правового регулювання конституційного права зі сферою політичних відносин, які вивчаються методами політичної науки. Так, окремі науковці (Н. Богашевська, Ю. Ключковський, Н. Мяловицька, В. Шаповал та ін.) наголошують, що конституційне право регулює відносини державного владарювання, тобто суспільні відносини, пов'язані з організацією та здійсненням публічної влади, що свідчить про вплив конституційного права на політичні відносини. Вони розглядають такий зв' язок природним «...для виборчого права, оскільки у виборчому процесі надзвичайно тісно переплітаються правові відносини і політична боротьба» [5].

Отже, під виборчою системою, на думку автора, слід розуміти систему суспільних відносин, які складаються у зв'язку з виборами органів публічної влади та визначають законодавчий порядок їх формування. Ці відносини регулюються конституційно-правовими нормами, які в сукупності утворюють конституційно-правовий інститут виборчого права.
Розглядаючи i аналізуючи виборче право як підгалузь конституційного права, слід розуміти його як в об' єктивному, так і в суб'єктивному значенні. Об'єктивне виборче право це один із головних конституційно-правових інститутів, зміст якого складають норми, що регулюють суспільні відносини, пов'язані з формуванням представницьких та інших виборних органів публічної влади (державної влади і місцевого самоврядування). Цей інститут характеризується такими особливостями: 1) він більшою мірою (порівняно з іншими конституційно-правовими інститутами) зазнає впливу норм міжнародного права; 2) значна частина його норм є полівалентними, тобто такими, що одночасно належать до двох та більше галузей права; 3) переважна більшість норм цього інституту є процесуальними нормами. Норми інституту виборчого права встановлюють: принципи виборчого права; вимоги до виборців і кандидатів; порядок утворення та діяльності виборчих органів; процедуру висування і реєстрації кандидатів; статус виборців та інших суб'єктів виборчого процесу; процедуру ведення передвиборної агітації та голосування; порядок визначення результатів виборів тощо.

Суб'єктивне виборче право, зокрема в Україні, традиційно закріплюється Конституцією і розглядається як гарантоване державою право громадянина України вільно обирати та бути обраним до виборних органів публічної влади (державної влади і місцевого самоврядування). При цьому виокремлюються активне (право обирати) та пасивне (право бути обраним) виборче право.

Таким чином, історико-правовий аналіз еволюції виборчої системи в Україні в її конректно-історичних формах має враховувати, що, по-перше, неодмінною передумовою ефективного, в інтересах суспільства функціонування тієї чи іншої виборчої системи на конкретному етапі історичного розвитку є забезпечення та дотримання державою принципів виборчого права, зафіксованих в конституції та виборчому законодавстві з обов' язковою гарантією та дотриманням конституційності виборного органу. По-друге, виборча система має сприйматися суспільством як об'єктивна і справедлива. Яку б розумну виборчу систему не було сконструйовано, якщо суспільство буде вважати, що вона спрямована на маніпулювання волею виборців, якщо вона викликатиме суспільну недовіру, така система не буде сприйнята. Тим самим, вибори оцінюються як недемократичні, а легітимність їх результатів є сумнівною. По-третє, у функціонуванні виборчої системи завжди слід враховувати фактор політичної доцільності. Проте, як справедливо наголошує Ю.Ключковський: «...політичними цілями, які ставляться при відборі системи, мають бути не вузькопартійні цілі, переваги конкретних партій чи кандидатів перед їх конкурентами, а цілі суспільно-політичні, загальні, спільні для всіх....» [19, с. 121-122]. Водночас важлива, на нашу думку, гарантованість дотримання двох чинників - правового та суспільного.

3 огляду на вищенаведене можна констатувати, що виборчу систему в історико-правовому вимірі слід розуміти таким чином. Виборча система - це врегульована конституційно-правовими нормами (в сукупності утворюють конституційно-правовий інститут виборчого права) система суспільних відносин, які складаються в рамках врегульованого законом порядку організації та проведення вільних виборів, як форми прямої демократії та безпосереднього народовладдя, завдяки якій 
отримують можливість на законних підставах (легально) та на основі загальносуспільного визнання (легітимно) функціонувати представницькі органи публічної влади на окремому історичному етапі розвитку суспільства.

Таким чином, можна зробити висновок, що виборча система відіграє важливу роль у процесі формування політичної волі в Україні, а здатність їі забезпечити між різними політичними партіями консенсус в процесі боротьби за владу є важливим фактором стабільності та руху вперед.

\section{Jimepamypa:}

1. Авдеенкова М. Современные избирательные системы. Выборы. Законодательство и технологии. 2000. № 7/8. С. 54-59.

2. Бабкін В.Д. Вид правової та соціально-правової держави. Правова держава : щоріч. наук. пр. / Ін-т держави і права ім. В.М. Корецького НАН України. Київ, 2001. Вип. 12. С. 270-281.

3. Бабкін В.Д. Соціальна держава та захист прав людини. Правова держава : щоріч. наук. пр. Ін-т держави і права ім. В.М. Корецького НАН України. Київ, 1998. Вип. 9. С. 3-11.

4. Бандурка О.М. Парламентаризм в Україні: становлення і розвиток. Університет внутрішніх справ. Харків, 1999. 288 с.

5. Богашевська Н. Еволюція виборчої системи в Україні [Електронний ресурс] / Наталія Богашевська, Юрій Ключковський. Bicник Центральної виборчої комісї / Центральна виборча комісія. URL: http://www.cvk.gov.ua/visnyk/index.php?mID=12.

6. Бурлак О.В. Поняття міжнародного стандарту у міжнародному праві прав людини - новий етап розвитку. Держава і право : збірник наукових праць. Київ, 2006. Вип. 33. С. 509-515.

7. Буроменский М.В. Политические режимы государств в международном праве. Влияние международного права на политические режимы государств. Харьков : Ксилон, 1997. 243 с.

8. Виборче право України : навч. посіб. / НАН України, Ін-т держави і права ім. В.М. Корецького ; ред. В.Ф. Погорілко, М.І. Ставнійчук. Київ : Парламентське видавництво, 2003. 383 с.

9. Грушевский М.С. Очерк истории украинского народа / Акад. наук УРСР, Михаил Грушевский; [сост. и ист.-биогр. очерк: Ф.П. Шевченко, В.А. Смолия; примеч. : В.М. Рички, А.И. Гуржия]. Киев : Лыбидь, 1991. 400 с.

10. Грушевський М.С. Історія України-Руси : [в 11 т., 12 кн.] Т. 3. До року 1340; [ред. кол.: П.С. Сохань (голова), С.І. Білокінь, Г.В. Боряк та ін.] ; Археографічна комісія АН УРСР, Ін-т історії України АН УРСР [та ін.]. Київ : Наук. думка, 1993. 586 с.

11. Даль Р.А. О демократии = On democracy; [пер. с англ. А.С. Богдановского]. Москва : Аспент пресс, 2000. 203 с.

12. Дарендорф Р. Современный социальный конфликт. Очерк политики свободы; [пер. с нем. Л. Ю. Пантиной]. Москва : РОССПЭН, 2002. 284, [2] с. (Университетская библиотека. Политология).

13. Дністрянський С. Загальна наука права і політики. Т. 1 / Степан Дністрянський. Прага : Наклад Українського Університету в Празі, 1923.400 с.

14. Драгоманов М.П. Вибране («...мій задум зложити очерк історії цивілізації на Україні»); [упоряд. та авт. іст.-біогр. нарису Р.С. Міщук ; приміт. Р.С. Міщука, В.С. Шандри]. Київ : Либідь, $1991.688 \mathrm{c}$

15. Древаль Ю.Д. Парламентаризм у політичній системі України (політико-правовий аналіз): монографія; Національний ун-т внутрішніх справ. Харків : Вид-во Нац. ун-ту внутрішніх справ, $2003.280 \mathrm{c}$.

16. Зіллер Ж. Політико-адміністративні системи країн ЄС: порівняльний аналіз ; [пер. з фр. В. Ховхун]. Київ : Основи, 1996. 420 с.

17. Каменская Г.В. Генезис идей демократии. Социс $=$ Социологические исследования. Москва, 1994. № 4. С. 29-40.

18. Каррі Д.П. Конституція Сполучених Штатів Америки : посіб. для всіх; [пер. з англ. О. Мокровольський]. Київ : Веселка, 1993. 192 с.
19. Ключковський Ю.Б. Виборчі системи та українське виборче законодавство : монографія ; Нац. ун-т «Києво-Могилянська Академія». Київ : Час Друку, 2011. 132 с.

20. Ключковський Ю.Б. Принципи виборчого права: законодавче застосування і реалізація. Вибори і референдум в Україні: законодавче забезпечення, проблеми та шляхи вдосконалення : зб. матеріалів міжнар. наук.-практ. конф. Київ, 2003. С. 41-53.

21. Ковальчук О.Б. Виборчий процес в Україні: конституційно-правові аспекти : автореф. дис. ... канд. юрид. наук : спец. 12.00.02; Одеська нац. юрид. акад. Одеса, 2003. 20 с.

22. Козодой Л.М. Конституційно-правовий статус суб'єктів виборчого процесу в Україні : дис. ... канд. юрид. наук : спец. 12.00.02 ; Київ. нац. ун-т внут. справ. Київ, 2006. 227 с.

23. Конституционное (государственное) право зарубежных стран. Общая часть : учебник / [рук. авт. колл. и отв. ред. д.ю.н., проф. Б.А. Страшун]. 4-е изд., обновл. и дораб. Москва : Норма, 2007. $896 \mathrm{c}$.

24. Конституційне право України : підручник / Мін-во освіти і науки України, Нац. юрид. акад. України ім. Ярослава Мудрого ; за ред. : В.П. Колісника, Ю.Г. Барабаша. Харків : Право, 2008. 416 с.

25. Конституція України від 28 червня 1996 року

26. Кофман Б. Міжнародні виборчі стандарти: ідентифікаційна структурна характеристика. Вісник Центральної виборчої комісії. Київ, 2007. № 3. C. 74-80.

27. Кравченко В.В. Конституційне право України : навч. посіб.; Ін-т економіки та права «Крок». 2-ге вид., допов. Київ : Атіка, 2002. $480 \mathrm{c}$.

28. Лейпхарт А. Демократии : типы мажоритарного и консенсусного правления в двадцати одной стране. Москва : Наука, 1984. 184 с.

29. Марченко М.Н. Теория государства й права : учебник. МГУ им. М.В. Ломоносова. 2-е изд., перераб. и доп. Москва : [ООО «Изд. Проспект], 2004. 640 с.

30. Михальченко М. Порівняльний аналіз європейських виборчих систем. Наукові записки Інституту політичних і етнонаціональних досліджень ім. І. Ф. Кураса. Київ, 2010. Вип. 6. С. 267-286.

31. Осипова Н.П. Політико-правовий інститут як суб'єкт реалізації законності. Проблеми законності : республ. міжвід. наук. зб. Харків, 2003. Вип. 60. С. 189-199.

32. Основи конституційного права України : підручник/[М.І. Козюбра, А.М. Колодій, ВВ. Копєйчиков та ін.] ; за ред. В.В. Копєйчикова ; Нац. пед. ун-т ім. М.П. Драгоманова. Київ : Юрінком Інтер, 1998. $287 \mathrm{c}$.

33. Підгорна О.А. Роль міжнародних стандартів виборчого права в реалізації принципів безпосередньої демократії. Актуальні проблеми держави і права : 3б. наук. пр. Одеса, 2004. Вип. 22. С. 278-282.

34. Поппер К. Відкрите суспільство та його вороги. Т. 1. У полоні Платонових чарів / Карл Поппер ; [пер. $з$ англ. О. Коваленко]. Київ : Основи, 1994. 444 с.

35. Популярна юридична енциклопедія / [В.К. Гіжевський, В.В. Головченко, Е.Ф. Демський та ін. ; кер. В.С. Ковальський]. Київ : Юрінком Інтер, 2003. 528 c.

36. Сарторі Дж. Порівняльна конституційна інженерія : дослідження структур, мотивів і результатів; [пер. 3 2-го англ. вид.]. Київ : Артек, 2001. $211 \mathrm{c}$.

37. Селіванов В.М. Право і влада суверенної України : методологічні аспекти : монографія; Акад. прав. наук України. Київ : Вид. дім «Ін Юре», 2002. 724 c.

38. Токвиль А. де. Демократия в Америке; [пер. с франц. В.П. Олейника, Е.П. Орловой, И.А. Малаховой и др.] ; предисл. Гарольда Дж. Ласки ; комм. В.Т. Олейника. Москва : Прогресс, 1992. 554 с.

39. Требков А.А. Узнать международные стандарты прав человека. Государство и право. Москва, 1993. № 10. С. 142-150.

40. Україна в сучасному світі : конф. випускників програм наукового стажування у США / Kennan Institute ; Woodrow Wilson 
International Center for Scholars ; [голова ред. кол. О.В. Гарань]. Ялта ; Київ : Стилос, 2003. 394 с.

41. Український парламентаризм: минуле і сучасне / [Ю.С. Шемшученко, О.М. Мироненко, В.Ф. Погоріло] ; Ін-т держави і права ім. В.М. Корецького НАН України ; за ред. Ю.С. Шемшученка. Київ : Парламентське видання, 1999. 367 с.

42. Юридична енциклопедія : в 6 т. Т. 1. А - Г / Нац. акад. наук України, Ін-т держави і права ім. В.М. Корецького НАН України ; [ред. кол. : Ю.С. Шемшученко (головний ред.), М.П. Зяблюк, В.П. Горбатенко та ін.] Київ : «Українська енциклопедія» ім. М.П. Бажана, $1998.672 \mathrm{c}$.

Pavlenko V. Elections and the electoral system in Ukraine: historical and legal analysis

Summary. The relevance of the article is that since independence Ukraine has used all existing electoral models: majority, proportional and mixed. But, unfortunately, it should be acknowledged that the elections in Ukraine in the post-communist period were and are held, as a rule, using the methods of administrative pressure, bribery of the population, intimidation of candidates and voters. In the article the formation of the electoral system in Ukraine is analyzed. The essence of the concepts "elections" and "electoral system" is revealed, domestic and foreign experience of their development is shown. The role of elections for any democratic state is determined. Ways of further development of the electoral system in Ukraine are considered. The need to study the history of the electoral system of our state is emphasized. Conceptual approaches to improving the electoral legislation of Ukraine are outlined. It is emphasized that the political and legal dimension of the electoral system integrates the legal and political aspects of the electoral process and means the procedure for organizing and conducting elections to representative bodies of government and the exercise of citizens' voting rights. In this case, the electoral system is seen as an element of the political system that organizes and serves the institution of elections, established by law or other regulations by way of determining the results of voting and the distribution of seats between parties and candidates. It was found that subjective suffrage, particularly in Ukraine, is traditionally enshrined in the Constitution and is considered a state-guaranteed right of a citizen of Ukraine to freely elect and be elected to elected bodies of public authority (state power and local self-government). At the same time, active (right to vote) and passive (right to be elected) suffrage are distinguished. It is concluded that the electoral system is a system of public relations regulated by constitutional and legal norms (together form the constitutional and legal institution of electoral law), which is formed within the statutory procedure for organizing and holding free elections as a form of direct democracy and direct democracy which have the opportunity on legal grounds (legally) and on the basis of public recognition (legitimately) to function representative bodies of public authority at a particular historical stage of development of society.

Key words: elections, electoral system, electoral legislation, historical and legal analysis, democracy. 